\title{
Lycopene Concentration of Tomato Fruit can be Estimated from Chromaticity Values
}

\author{
Mervyn C. D'Souza', Suman Singha ${ }^{2}$, and Morris Ingle \\ Division of Plant and Soil Sciences, West Virginia University, \\ Morgantown, WV 26506-6108
}

Additional index words. Lycopersicon esculentum, tristimulus colorimeter

Abstract. Chromaticity values ( $\left.\mathrm{L}^{*}, \mathrm{a}^{*}, \mathrm{~b}^{*}\right)$ of tomato (Lycopersicon esculentum Mill. 'Celebrity', 'Early Pick', and 'Mountain Delight') were measured using a Minolta CR200b tristimulus colorimeter. Lycopene concentrations in acetone extracts of skin disks or pericarp plugs were measured spectrophometrically at $503 \mathrm{~nm}$. The $\mathrm{L}^{*}$ or a* value was related to lycopene concentration in all the cultivars; however, the ratio of $(a * /$ $\left.b^{*}\right)^{2}$ provided the best $\boldsymbol{R}^{2}$ for all cultivars $(0.75)$. These relationships allow the use of a portable colorimeter for rapid, nondestructive estimation of tomato fruit lycopene concentrations in laboratory or in situ studies.

Color is an important quality attribute of fruits and vegetables. It is the initial factor that consumers evaluate; if the color is unappealing, they are often unlikely to purchase the produce (Francis, 1980). Consumers prefer tomatoes that are harvested 'red ripe' (Kader et al., 1977; Watada and Aulenbach, 1979). Color or pigment changes during tomato ripening are characterized by loss of chlorophyll and a rapid accumulation of carotenoids, particularly lycopene. Lycopene is the predominant pigment in tomato that imparts the attractive redness.

Lycopene concentration in tomatoes can be determined accurately in the laboratory by spectorphotometric measurements of tissue extract obtained with acetone (Mencarelli and Saltveit, 1988). However, this procedure is time-consuming and destructive. Nondestructive, external measurement of fruit color provides a less tedious method for assessing ripening than the chemical analysis of pigments. Measurement of color is closely related to visual perception in apples (Malus domestica Borkh.) (Singha et al., 1991b) and tomatoes (Shewfelt et al., 1988). Goodenough et al. (1982) used a* values to monitor color development during storage of tomatoes. Yang et al. (1990) measured tomato color using a Gardner colorimeter and expressed values as color difference (A E) and hue angles ( $\left.\tan ^{-1} \mathrm{~b} / \mathrm{a}\right)$. In both these studies, chromaticity values were not tested in relation to lycopene content. Edwards et al. (1983) correlated lycopene content of pericarp disks and the ratio of reflec-

Received for publication 29 Apr. 1991. Accented for publication 2 Dec. 1991. Approved for publication by the Director, West Virginia Agr, and For. Expt. Sta., as Scientific Article no. 2279. The cost of publishing this paper was defrayed in part by the payment of page charges. Under postal regulations, this paper therefore must be hereby marked advertisement solely to indicate this fact. 'Current address: Technical Center, Knouse Foods, P.O. Box 709, Biglerville, PA 17307.

${ }^{2}$ Current address: Dept. of Plant Science, The Univ. of Connecticut, Storrs, CT 06269-4067. tance at 550 and $650 \mathrm{~nm}$, but the procedure used was destructive. Nondestructive measurement of chromaticity values with a colorimeter would be useful if it accurately estimated lycopene concentration of tomato samples in situ or after harvest. The objective of this study was to establish a relationship between chromaticity values determined nondestructively and lycopene concentrations in tomato skin disks and pericarp plugs.

Fruit of 'Celebrity', 'Early Pick', and 'Mountain Delight' tomatoes were obtained from a commercial source. Fruit were selected to encompass varying colors, from green to red-ripe. After the fruit was washed and dried, color was measured with a Min- olta Chroma Meter CR-200b portable tristimulus colorimeter (Minolta, Ramsey, N.J.). Measurements were made by placing the 8mm-diameter measuring area of the apparatus at the midpoint between the stem and calyx ends at four quadrants on each tomato. There were a total of 30 tomatoes of each cultivar. Fruit chromaticity was recorded in Commission Internationale de'Eclairage L*, $a^{*}$, and $b^{*}$ color space coordinates (Hunter, 1975). The meter was calibrated at illuminant condition $C(6774 \mathrm{~K})$ with a white standard (Minolta calibration plate CR-A43) before use.

Following color measurement, the fruit were stored in a freezer (-15C, in darkness). Lycopene extractions of skin disks and pericarp plugs were conducted immediately after removal of the fruit from storage. Individual skin disks corresponding to the locations of chromaticity measurements were removed with a 10 -mm cork borer. Disks (free of adhering mesocarp) were extracted in $3 \mathrm{ml}$ of acetone in darkness to prevent light-induced oxidation of lycopene. Extraction was on a rotary shaker at $150 \mathrm{rpm}$ for $1 \mathrm{~h}$. The acetone extract was centrifuged at $1000 \times g$ for 10 min, and absorbance of the supernatant was measured at $503 \mathrm{~nm}$ using a Milton Roy Spectronic Plus spectrophotometer (Milton Roy, Rochester, N.Y.). Lycopene concentration was calculated using the molar extinction coefficient of $17.2 \times 10^{4} \mathrm{~mol} \cdot \mathrm{cm}^{-1}$ (Beerh and Siddappa, 1959). Lycopene concentration of weighed frozen pericarp plugs was determined by a modification of the procedure proposed by Mencarelli and Saltveit (1988). Instead of homogenizing the tissue, the plugs ( 0.3 to $0.4 \mathrm{~g}$ ) were diced with a

Table 1. Coefficient of determination $\left(R^{2}\right)$ for selected models relating chromaticity values to lycopene concentration in fruit of three tomato cultivars.

\begin{tabular}{|c|c|c|c|}
\hline \multirow{2}{*}{$\begin{array}{l}\text { Chromaticity } \\
\text { values }\end{array}$} & \multirow[b]{2}{*}{ Cultivar } & \multicolumn{2}{|c|}{ Tissue sampled } \\
\hline & & Skin disks & Pericarp plugs \\
\hline $\mathrm{L}^{*}$ & $\begin{array}{l}\text { Celebrity } \\
\text { Early Pick } \\
\text { Mountain Delight }\end{array}$ & $\begin{array}{l}0.69^{*} \\
0.77^{*} \\
0.82^{*}\end{array}$ & $\begin{array}{l}0.66^{*} \\
0.64^{*} \\
0.77^{*}\end{array}$ \\
\hline$a^{*}$ & $\begin{array}{l}\text { Celebrity } \\
\text { Early Pick } \\
\text { Mountain Delight }\end{array}$ & $\begin{array}{l}0.55^{*} \\
0.58^{*} \\
0.68^{*}\end{array}$ & $\begin{array}{l}0.75^{*} \\
0.69^{*} \\
0.63^{*}\end{array}$ \\
\hline$b^{*}$ & $\begin{array}{l}\text { Celebrity } \\
\text { Early Pick } \\
\text { Mountain Delight }\end{array}$ & $\begin{array}{l}0.31^{*} \\
0.34^{*} \\
0.06^{\mathrm{NS}}\end{array}$ & $\begin{array}{l}0.07^{\mathrm{NS}} \\
0.01^{\mathrm{NS}} \\
0.14^{\mathrm{NS}}\end{array}$ \\
\hline$\left(a^{*} / b^{*}\right)$ & $\begin{array}{l}\text { Celebrity } \\
\text { Early Pick } \\
\text { Mountain Delight }\end{array}$ & $\begin{array}{l}0.71^{*} \\
0.73^{*} \\
0.69^{*}\end{array}$ & $\begin{array}{l}0.73^{*} \\
0.72^{*} \\
0.72^{*}\end{array}$ \\
\hline$\left(a^{*} / b^{*}\right)^{2}$ & $\begin{array}{l}\text { Celebrity } \\
\text { Early Pick } \\
\text { Mountain Delight }\end{array}$ & $\begin{array}{l}0.83^{*} \\
0.71^{*} \\
0.80^{*}\end{array}$ & $\begin{array}{l}0.67^{*} \\
0.77^{*} \\
0.75^{*}\end{array}$ \\
\hline $\begin{array}{l}\tan ^{-1} b^{*} / a^{*} \\
\text { (hue angle) }\end{array}$ & $\begin{array}{l}\text { Celebrity } \\
\text { Early Pick } \\
\text { Mountain Delight }\end{array}$ & $\begin{array}{l}0.22^{\mathrm{Ns}} \\
0.14^{\mathrm{Ns}} \\
0.29^{\mathrm{Ns}}\end{array}$ & $\begin{array}{l}0.26^{\mathrm{NS}} \\
0.24^{\mathrm{NS}} \\
0.22^{\mathrm{NS}}\end{array}$ \\
\hline $\begin{array}{c}\sqrt{a^{* 2}+b^{* 2}} \\
\text { (Chroma) }\end{array}$ & $\begin{array}{l}\text { Celebrity } \\
\text { Early Pick } \\
\text { Mountain Delight }\end{array}$ & $\begin{array}{l}0.10^{\mathrm{NS}} \\
0.08^{\mathrm{NS}} \\
0.26^{\mathrm{NS}}\end{array}$ & $\begin{array}{l}0.67^{*} \\
0.26^{\mathrm{NS}} \\
0.01^{\mathrm{NS}}\end{array}$ \\
\hline
\end{tabular}

Ns, ${ }^{*}$ Nonsignificant or significant at $P \leq 0.05$. 

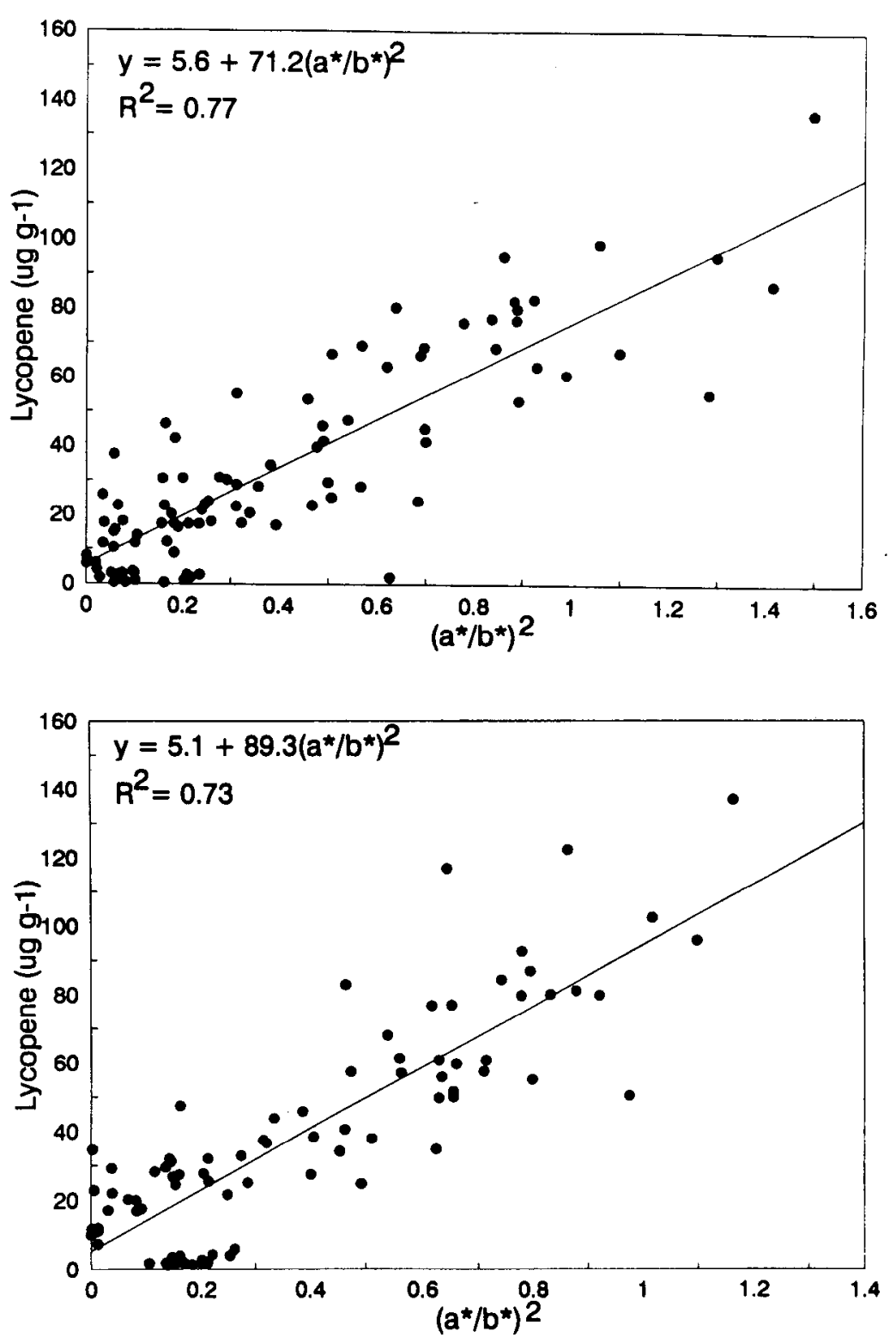

Fig. 1. Relationship between extractable lycopene and $\left(\mathrm{a}^{*} / \mathrm{b}^{*}\right)^{2}$ values measured from tomato skin disks (top) and pericarp plugs (bottom).

scalpel and extracted in $4 \mathrm{ml}$ of acetone. Extraction was in darkness on a rotary shaker at $200 \mathrm{rpm}$ for $3 \mathrm{~h}$. Data were analyzed by general linear models procedure and regression analysis (SAS Inst., 1982).

Several simple linear regression models used to relate chromaticity values to lycopene concentrations produced varying results (Table 1). L*, which represents degree of lightness, provided a reasonably good fit $\left(R^{2}=0.64\right.$ to 0.82$)$ for all three cultivars irrespective of the tissue type (skin disks or pericarp plugs). The $a^{*}$ value (a measure of redness) was a fairly good predictor in all the cultivars when pericarp plugs were used; centration in most cases (Table 1).

The ratio $\left(a^{*} / b^{*}\right)^{2}$ was chosen to develop regression equations (Fig. 1) because it was consistently well related to lycopene concentrations. More complex regression models for each cultivar yielded $R^{2}$ values as high as 0.89 (data not shown). The variable(s) selected to develop regression equations will depend on the cultivar and/or the amount of predictability needed for a particular investigation. The models do not predict lycopene concentration accurately enough to substitute entirely for chemical extractions; however, they are useful for screening or estimating lycopene concentrations, especially in in situ studies because the colorimeter is portable.

\section{Literature Cited}

Beerh, O.P. and G.S. Siddappa. 1959. A rapid spectrophotometric method for the detection and estimation of adulterants in tomato ketchup. Food Technol. 13:414-418.

Edwards, J.I., M.E. Saltveit, Jr., and W.R. Henderson. 1983. Inhibition of lycopene synthesis in tomato pericarp tissue by inhibitors of ethylene biosynthesis and reversal with applied ethylene. J. Amer. Soc. Hort. Sci. 108:512514.

Francis, F.J. 1980. Color quality evaluation of horticultural corps. HortScience 15:58-59.

Goodenough, P.W., G.A. Tucker, D. Grierson, and T. Thomas. 1982. Changes in color, polygalacturonase monosaccharides and organic acids during storage of tomatoes. Phytochemistry 21:281-284.

Hunter, R.S. 1975. The measurement of appearance. Wiley-Interscience, New York.

Kader, A.A., M.A. Stevens, M. Albright-Holton, L.L. Morris, and M. Algazi. 1977. Effect of fruit ripeness when picked on flavor and composition in fresh market tomatoes. J. Amer. Soc. Hort. Sci. 102:724-731.

Mencarelli, F. and M.E. Saltveit, Jr. 1988. Ripening of mature-green tomato fruit slices. J. Amer. Soc. Hort. Sci. 113:742-745.

SAS Institute. 1982. SAS user's guide. SAS Institute, Cary, N.C.

Shewfelt, R.L., C.M. Thai, and J.W. Davis. 1988 Prediction of changes in color of tomatoes during ripening at different constant temperatures. J. Food Sci. 53:1433-1437.

Singha, S., T.A. Baugher, E.C. Townsend, and M.C. D'Souza. 1991a. Anthocyanin distribution in 'Delicious' apples and the relationship between anthocyanin concentration and chromaticity values. J. Amer. Soc. Hort. Sci. 116:497-499.

Singha, S., E.C. Townsend, and T.A. Baugher 1991b. Relationship between visual rating and chromaticity values in 'Delicious' apple strains. Fruit Var. J. 45:33-36.

Watada, A.E. and B.B. Aulenbach. 1979. Chemical and sensory qualities of fresh market tomatoes. J. Food. Sci. 44:1013-1016.

Yang, R.F., T.S. Cheng, and R.L. Shewfelt. 1990 The effect of high temperature and ethylene treatment on the ripening of tomatoes. J. Plant Physiol. 136:368-372. 